\title{
天然および養殖アユのリポキシゲナーゼ様䤏素と 香気成分の生成について
}

\author{
章超樺, 白井隆明, 鉿木 健, 平野敏行 \\ (1991 年 11 月 15 日受付)
}

\author{
Lipoxygenase-like Activity and Formation of Characteristic Aroma \\ Compounds from Wild and Cultured $\mathrm{Ayu}^{* 1}$ \\ Chao-Hua Zhang, ${ }^{* 2, * 8}$ Takaashi Shirai,*2 Takeshi Suzuki, *2 \\ and Toshiyuki Hirano*2
}

\begin{abstract}
Lipoxygenase-like activity was found in the crude extracts from the skin and gill of wild and cultured ayu. After incubation of arachidonic acid with the crude extract from the wild and cultured ayu skins, the major oxygenated product was estimated to be 12-hydroxyeicosatetraenoic acid under high-performance liquid chromatography using a Waters $\mu$ bondapak fatty acid column. On the other hand, eicosapentaenoic acid yielded 12-hydroxyeicosapentaenoic acid. This enzyme activity of wild and cultured ayu was inhibited strongly in the presence of the following reagents: $\mathrm{BHA}$, esculetin, $p$-chloromercuribenzoate, $\mathrm{SnCl}_{2}, \mathrm{CuCl}_{2}$.

The $C_{\theta}$ carbonyl compounds and alcohols specifically formed from the oxidation of poly. unsaturated fatty acids in the crude extract of wild ayu skin. In GC-MS chromatogram, a peak height of $(E, Z)-2,6$-nonadienal formed from the wild ayu skin was higher than that of the cultured ayu skin, while that of 3,6-nonadien-1-ol from the wild ayu skin was lower than that from the cultured fish skin.
\end{abstract}

責殖アニは天然アニに比べて独特の香気に久け，外 観，食味に颃いて天然了二に及ばないと言われている。 著者らは着殖アユの品質向上のために，これまで生鮮の 天然扣よび養殖ア二の香気の本体を解明し，年の查気成 分の来源を追究した。 ${ }^{1-2)}$ 羡殖〉二の特有のに打い成分 は魚体内のリポキシゲナーゼ（以下 LOX 々略記）樣醭 菜に上る高度不飽和脂肪酸の酸化から生成されることを

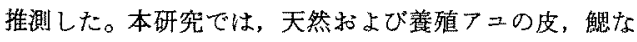
どから粗酵素液を調製し，LOX 様醉素の特徽を調べた。 また，天然了二の皮の粗酵素液を用いて醉素的に由来寸 る䩑発性生成物を検索し，天然括上び羕殖つュの香気成 分の生成の差異を比較検討した。

\section{実 験 方 法}

試料 天然アニは，1991 年 7 月と 8 月の 2 回にわ たり，栃木県那珂川と同県思川の上流で友釣りにより採 捕したものを直らに採捕地で液体空素により急速凍結
し，ドライフイスを入れたアイスボックスに詰め，研究 室に持ら㛿った。湌殖フ二は1991 年 7 月, 東京都中央 卸売市場 (築地) から愛知県産のものを活魚て購入し, 天然アニと同様に処理して用いた。

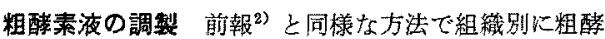
素液の調掣を行ったが，リン酸塩楥衙渡の代わりに， $0.05 \mathrm{M}$ Tris- $\mathrm{HCl}$ (pH 7.4) 缓衝液を使用した。

モノヒトロロシ酸の抽出と分析 飯島ら*4の力法に準 し. 粗醉菜液 $15 \mathrm{ml}$ を $20^{\circ} \mathrm{C} て ゙ 1$ 分間インキュベート 後，アラキドン酸要たはエイコサペンタエン酸 (EPA) の土タノール溶液 $(100 \mu \mathrm{M})$ を添加した。これを $20^{\circ} \mathrm{C} 10$

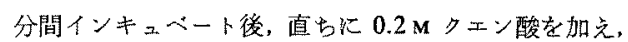
pH 3 4 KLて反応老停止させた。它の後, 3 倍量のシ エチルエーテルで 3 回抽出し, エーテル嵓を約 $20 \mathrm{ml}$ まで減压濃縮させた。これに数滴の水を加光，2,000 rpm で遠心分離した後，エーテル屡を無水硫酸ナトリウムカ ラム $(15 \times 50 \mathrm{~mm})$ に通した。䬽水後, 再び溶媒を除

*1 魚類のに招いに関する食品化学的研究一IV (Studies on the Odor of Fishes-IV).

*2 東京水産大学食品生産学科 (Department of Food Science and Technology, Tokyo University of Fisheries, Konan, Minato, Tokyo 108, Japan).

*8 中国湛江水隡学院 (Zhanjiang Fisheries College, Jiefan Road, Xiashan Zhanjiang, Guangdong, China).

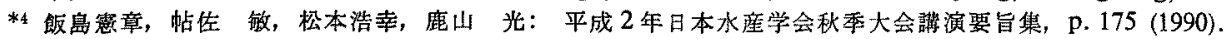


去し，得られた残さをへキサン/ジェチルエーテル (9:1， $\mathrm{V} / \mathrm{V}) 1 \mathrm{~m} l$ に溶かし，同溶媒で平衡化しておいたケイ酸 (約 $1 \mathrm{~g})$ カラムに通して $20 \mathrm{ml}$ の同溶媒でカラムを洗浄 し，遊離脂肪酸を溶出させた。っいでへキサン/ジェチ ルエーテル $(4: 6, \mathrm{~V} / \mathrm{V})$ の溶媒を $20 \mathrm{ml}$, さらにジェチル エーテル $10 \mathrm{~m} l$ を流してヒドロキシ酸画分を溶出させ た。この画分を減正乾固後, メタノ一ルに溶加し, 逆相 系のカラムを用いた HPLC (RP-HPLC) によって分析 した。なお，ヒドロキシ酸の標品として，Sigma 社製の 12-ヒドロキシエイコサテトラエン酸 (12-HETE) と 12ヒドロキシエイコサペンタエン酸 (12-HEPE) を用いた。 RP-HPLC の分析条件として, JASCO BIP-1 HPLC (日 本分光製)， $\mu$ Bondapak 脂肪酸分析用力ラム $(3.9 \mathrm{~mm}$ $\times 30 \mathrm{~cm}$, Waters 製), JASCO 875-UV 紫外可視分光㭘 出器 (波長, $235 \mathrm{~nm}$, 日本分光製)，C-R6A クロトハッ クデータ処理器 (島津製) を用い，移䟚相として、ア七

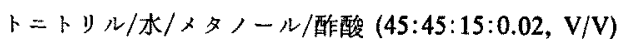
を使用し, 流量は $1 \mathrm{~m} / / \mathrm{min}$ とした。

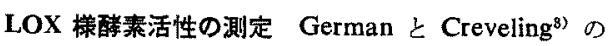
方法に準し，各試料魚の皮，鰓，筋肉の粗酵素液 $5 \mathrm{~m} l$ を $20^{\circ} \mathrm{C}$ で 1 分間インキュペート後, アラキドン酸エタ， ール溶液 $(100 \mu \mathrm{M})$ 添加し，10 分間インキュベート後,
直ちに 3\%のギ酸 $(1 \mathrm{ml})$ を加えて反応を停止させた。 その後 3 倍量の䤀酸エチルを加えて初期酸化生成物を 2 回抽出し.RP.HPLC の分析に供した。酵素活珄は基 質アラキドン酸から醉素反汇液 $1 \mathrm{~m} l$ 当たり，10 分間比 生成される $0.1 \mathrm{nmol} の 12$-HETEをるって 1 unitとし た。

酵素反応に由来する揮甡性成分の捕集と同定 即報2》 と同様にーッドスペース法による楎発性生成物の捕集虬 よび GC-MS による分析と同定を行った。

\section{結果および考察}

初期酸化生成物と酵素活性 ア二皮の粗醉素液にそれ ぞれアラキドン酸と EPA を添加して反応させた後，攴 れらの生成物であるもドロペルオキシドをとドロキシ体 として検出した。Fig. 1 に示す上らに，着殖て二と天然 アニにはいずれもアラキドン酸からはピーク 3, なた EPAからはピーク1 の生成が確認された。両ピーク

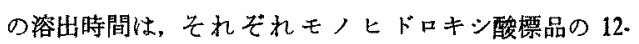
HETE (ピーク 3) と 12-HEPE (ピーク 1) のそれと一 致した。一方, 5 分間加熱した粗酵素液に基質アラキ ン酸を加えて同様に分析したところ,ピーク 3 は検出さ れなかった。German ら4) はニジマ解の 12-LOX K
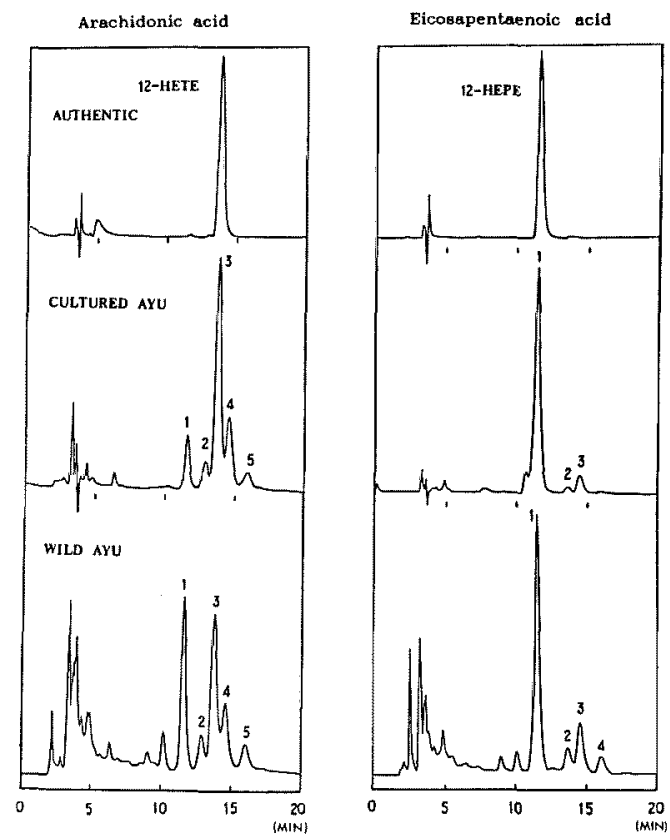

Fig. 1. Chromatograms of RP-HPLC for hydroxy fatty acids formed from the crude extract of wild and cultured ayu skins. Arachidonic or eicosapentaenoic acid was added to a final concentration of $100 \mu \mathrm{M}$ to the crude enzyme of wild and cultured ayu skins and incubated for $10 \mathrm{~min}$. Retention times of peaks were identical with those of authentic 12-hydroxyeicosatetraenoic acid (12-HETE) and 12-hydroxyeicosapentaenoic acid (12-HEPE). 
よるアラキドン酸と EPA の生成物として 12-HETE と 12-HEPE を同定している。アラキドン酸では，酸素 1 分子が付加されうる位圈は C $の 5,8,9,11,12,15$ 位

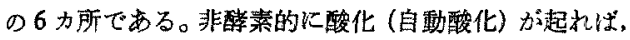
各種類のとドロペルオキシドェイュサテトラェン酸の混 合物が得られるが，LOX に上る醭反応では，そ小ら に位登特異性が見られる。占本研究ではフラキドン酸と $\mathrm{EPA}$ の酸化生成物については， $C_{12}$ の位置特異性や加熱 による阻害効果が示され，酵素的に由来するすのと思わ れる。

Table 1 は天然括よび養殖フ二組織別の LOX 様酵菜 活性を示したもので，両者を比較してみると，いずれる

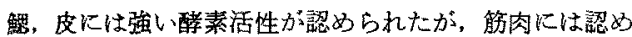
られなかった。この結果はすでに報告された多種魚類の それと一致している。ままた，既報の盖殖フコ2) とキュ ウリウオクでは醉菜的に生成した揮発性成分は鰓と皮に のみ見られ，本酵素はア二特有の香気成分の生成関与 することを明らかにした。LOX 様醉素は香気の強いる のほどその活性が強いと思われるが，天然アコと養殖つ ユの皮の酵素活性にはほとんど差が見られなかった。

LOX 槏醭素活性に及ほす試薬と金属イオンの影響 本研究においては，酵素活性は試楽無添加の活性值を $100 \%$ とし，相対活性で示した(Table 2)。天然招よび

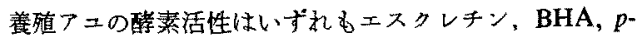
CMB によって著しく阻害され，過酸化水素とヨードア セトアミトによってる活性の低下が見られたが，エスタ

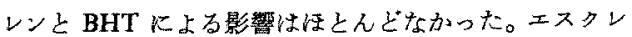

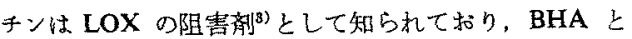
$p$-CMB すと報告されている。方， および着殖アニに対して，いずれ古活性化効果を示し た。aートコフェロールは，BHA と BHT と同しく酸化 防止剂として知られているか，10) 着殖つ二の粘液分泌を 増進する效果があるといわれている。その活性化効果は アニの香気生成にどのよらに関保しているのか, さらに

検討することが必要と考光られた。

この住，金属イオンを用いて LOX 様酳素に対する 影響を調べたところ, Table 3 に示すごとく, $\mathrm{Ca}^{2+}, \mathrm{K}^{+}$ および $\mathrm{Fe}^{2+}$ の影響は任とんどなかったが, $\mathrm{Sn}^{2+}, \mathrm{Cu}^{2+}$ の存在で, 活性が完全に阻害された。そのらち、, $\mathrm{SnCl}_{2}$ は LOX の特異的な阻害剂として報告されている。,11) 以上の結果から本醇素は12-LOX と推測されるが, さら に阻害剂に対する挙動を詳しく検討する必要があると思 われた。

天然アユの酳絭的に由来する揮発性生成物 天然フ二 の皮の粗酵菜液にりノール酸、リノレン酸, アラキドン 酸, EPA 扣よびドコサへキサエン酸（DHA）をそれそれれ
Table 1. Lipoxygenase-like activity in the crude extracts from ayu

(unit/mg protein)*

\begin{tabular}{ccccc}
\hline Sample & $\begin{array}{c}\text { Place of } \\
\text { catch }\end{array}$ & Gill & Skin & Muscle \\
\hline $\begin{array}{c}\text { Wild ayu } \\
\text { A }\end{array}$ & $\begin{array}{c}\text { Naka River, } \\
\text { Tochigi }\end{array}$ & 32 & 26 & 0 \\
B & $\begin{array}{c}\text { Omoi River, } \\
\text { Tochigi }\end{array}$ & 11 & 23 & 0 \\
$\begin{array}{c}\text { Cultured } \\
\text { ayu }\end{array}$ & $\begin{array}{c}\text { Fish farm, } \\
\text { Aichi }\end{array}$ & 17 & 23 & 0 \\
\hline$* \begin{array}{l}\text { One unit referes to the production of } 0.1 \text { nmol } 12- \\
\text { hydroxyeicosatetraenoic acid per ml after the 10 min } \\
\text { incubation at } 20^{\circ} \mathrm{C} \text { with substrate of arachidonic acid. }\end{array}$
\end{tabular}

Table 2. Effects of reagents on the lipoxygenase-like activity in the crude extract of ayu skin

\begin{tabular}{|c|c|c|c|}
\hline \multirow[b]{2}{*}{ Reagents } & \multirow{2}{*}{$\begin{array}{c}\text { Concentra- } \\
\text { tion } \\
(\mathrm{mm})\end{array}$} & \multicolumn{2}{|c|}{ Relative activity (\%) } \\
\hline & & $\begin{array}{c}\text { Cultured } \\
\text { ayu }\end{array}$ & $\begin{array}{l}\text { Wild } \\
\text { ayu }\end{array}$ \\
\hline None & - & 100 & 100 \\
\hline Esculetin & 0.01 & 22 & 26 \\
\hline Esculin & 0.01 & 98 & 100 \\
\hline \multirow[t]{2}{*}{$\mathrm{H}_{2} \mathrm{O}_{2}$} & 5 & 43 & \\
\hline & 1 & 36 & 67 \\
\hline BHA & 0.01 & 0 & 0 \\
\hline BHT & 0.01 & 96 & 108 \\
\hline \multirow[t]{3}{*}{$\alpha$-Tocopherol } & 1 & 193 & 150 \\
\hline & 0.1 & 100 & \\
\hline & 0.01 & 108 & \\
\hline$p-\mathrm{CMB}$ & 5 & 0 & 16 \\
\hline Iodoacetamide & 5 & 26 & 53 \\
\hline
\end{tabular}

Table 3. Effects of metal ions on the lipoxygenase-like activity in the crude extract of ayu skin

\begin{tabular}{|c|c|c|c|}
\hline \multirow[b]{2}{*}{ Metal } & \multirow{2}{*}{$\begin{array}{c}\text { Concentra- } \\
\text { tion } \\
(\mathrm{mM})\end{array}$} & \multicolumn{2}{|c|}{ Relative activity (\%) } \\
\hline & & $\underset{\text { ayu }}{\text { Cultured }}$ & $\begin{array}{l}\text { Wild } \\
\text { ayu }\end{array}$ \\
\hline None & - & 100 & 100 \\
\hline $\mathrm{CaCl}_{2}$ & 1.0 & 80 & 88 \\
\hline $\mathrm{KCl}$ & 1.0 & 94 & 79 \\
\hline $\mathrm{FeCl}_{2}$ & 1.0 & 98 & 74 \\
\hline $\mathrm{SnCl}_{2}$ & 5.0 & 0 & 15 \\
\hline $\mathrm{CuCl}_{2}$ & 1.0 & 0 & 0 \\
\hline
\end{tabular}

派加して反応させた。各々の揮発性生成物を捕集し， GC-MS で同定した。乞の結果,リノール酸, リノレン 酸の $\mathrm{C}_{18}$ ポリエン酸からは, 反店生成物は検出されなか ったが, Fig. 2 に示すように, n-6 系のアラキドン酸(A) と, $\mathbf{n}-3$ 系の EPA (B) と DHA (C) の両系列の間に, 異なった生成パターンが見られた。すなるる，アラキド 

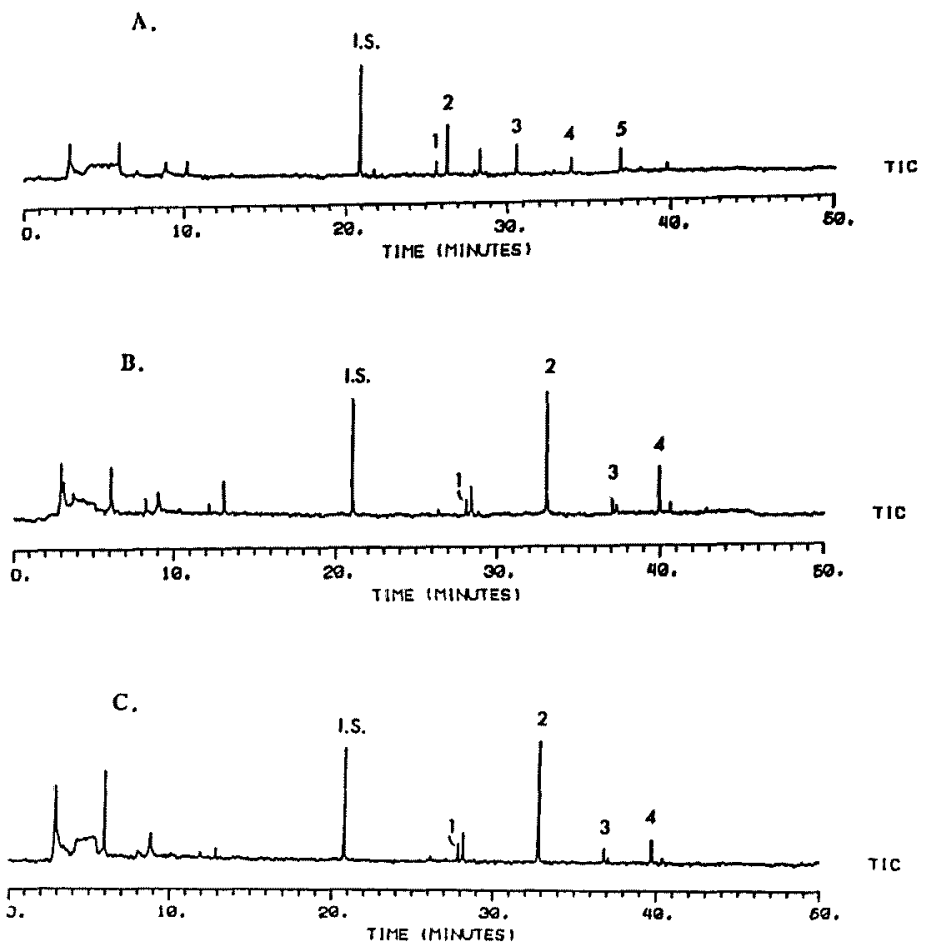

Fig. 2. Total ion chromatograms by GC-MS of volatile compounds formed from the crude extract of wild ayu skin incubated with arachidonic (A: 1, (E)-2-octenal; 2, 1-octen-3-ol; 3, (E)-2-nonenal; 4, (E)-2-octenol; 5, (Z)-3-nonenol), eicosapentaenoic, and docosahexaenoic acids (B and $\mathrm{C}:$ 1, 1,5-octadien-3-ol; 2, (E,Z)-2,6-nonadienal; 3, 2,5-octadien-1-ol; 4, 3,6nonadien-1-ol).

ン酸（A) では (E)-2-octenal (ピーク 1), 1-octen-3-ol (ピーク 2), (E)-2-nonenal (ピーク 3), (E)-2-octenol (ピ ーク4)乱よび (Z)-3-nonenol (ピーク5) の 5 成分, ま た, EPA (B) と DHA (C) ではいずれも 1,5-octadien3-ol (ピーク 1), (E,Z)-2,6-nonadienal (ピーク 2), 2,5octadien-1-ol (ピーク 3) 括よび 3,6-nonadien-1-ol (ピー ク 4)の 4 成分の生成が专れぞれ確認された。この結果 は既報の篦殖フユ2)のそれと同じであるが，等に(E,Z)2,6-nonadienal と 3,6-nonadien-1-ol の両成分の生成比 の違いが注目された。

Fig. 3 は天然アニと養殖アニ皮の粗䤃素に EPA を基 質として作用させ，醉菜的に生成した揮発珄成分の分析 結果を示したるのである。天然アュ(B)では、ピーク2の (E,Z)-2,6-nonadienal はピーク 4 の 3,6-nonadien-1-ol より多く生成されたが，荃殖つニでは，逆の㑯向を示し た。らなみに，に执いの特徵としては，前者はキュウリ 様臭で, ${ }^{12)}$ 後者はスイカのにおいが連想される。 雨成分の差がそれぞれ天然乱よび盖殖アュの香気パター ン1)に反映されることから，両者の香気の違いはこの両
成分の組成比に左右されるものと思われる。

香気成分の生成経路の推定 野菜や果物の持つさわや かな香気は，LOX の作用で生成した脂肪酸のヒドロぺ ルオキシトに电来する揮発性カルボニルやアルコール類 より賦与されることが知られて拈り，さらにLOX の活 がヒトロペルオキシドリアーゼやアルコールデヒドロ ゲナーゼなどの醉素も香気の生成に関与している。 ${ }^{14-18)}$

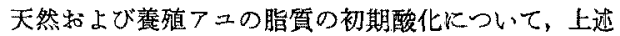
のように 12-LOX の作用が示唂されている。さらに, 醉 素反庆からアユ特有のカルボニル類とアルコール類が生 成されたことから，植物のものと同榚にLOX 以外の醉 素の関与が示唆される。

以上のことからアニ香気の主成分である $(\mathrm{E}, \mathrm{Z})-2,6-$ nonadienal Kついて，その生成経路を推測してみると， Fig. 4 亿示すよ 万K EPA は 12-LOX 様醉素の作用で， 12-ヒドロペルオキシドエイコサペンタエン酸 (n-9 ヒド ロペルオキシド多 が生成され，さらに酵素 2 のとドペ ルオキシドリフーゼによって短鎖の $C_{\theta}$ の 3,6-nonadienal が生成される。この $\mathrm{C}_{\vartheta}$ 中間生成物から, 酔素 $3 の$ 
A.
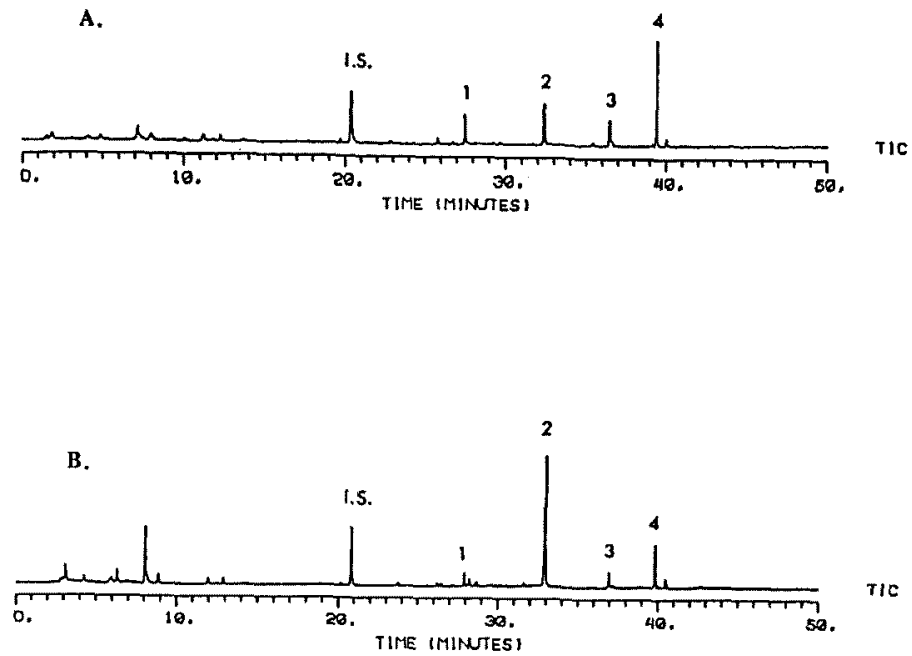

Fig. 3. GC-MS total ion chromatograms of volatile compounds formed from the crude extract of cultured (A) and wild ayu (B) incubated with eicosapentaenoic acid. 1, 1,5-octadien3-ol; 2, (E,Z)-2,6-nonadienal; 3, 2,5-octadien-1-ol; 4, 3,6-nonadien-1-ol.

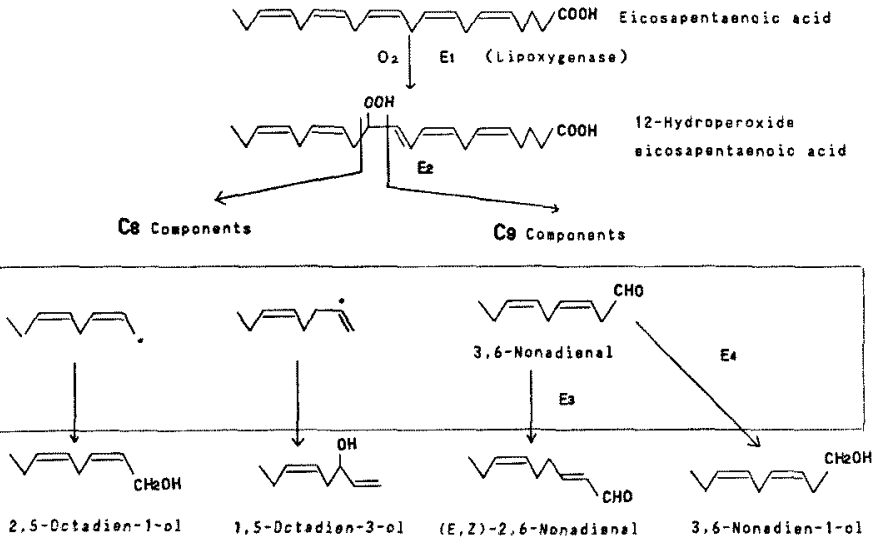

Fig. 4. Prospective pathways of formation of ayu volatile compounds from lipoxygenasecatalyzed oxidation of eicosapentaenoic acid in the ayu skin tissue.

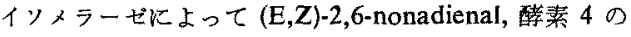
アルコールデとドロゲナーゼとよって3,6-nonadien-1-ol がをれぞれ生成されるものと思われる。C 8 の 1,5 octadien-3-ol そ2,5-octadien-1-ol はわ゙゙かに生成し, これは $\mathrm{C}_{\text {日 }}$ 生成物の副産物と思祘れる。Hsieh と Kinsella ${ }^{9)}$ はこれら $C_{8}$ 化合物の生成がフリーラジカルによ るものと指摘している。DHA あ EPA と同様な経路で 最初のn-9ヒドロペルオキシドから，中間体の 3,6-nonadienal を経て，最終的に $C_{8}$ 化合物が生成していくも のと考克られる。アラキドン酸の場合も，初期酸化産物 の n-9 ヒドロペルオキシドから (Z)-3-nonenal の中間体 が生成され，さらに酵素 3 Kよって(E)-2-nonenal が生
成されるわのと推测される。

\section{天然および養殖アユの香気生成に及ほす影幚因子 - -}

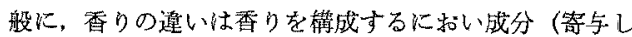
ている揮発性物質)の秏類とその相対裖度 (量比)によっ て決まると考えられる。㫜天然和上び䖯殖つニの香気に 寄与する揮発性物質の種頪が同じで, ‘息り香り違い は前述のよ5K(E,Z)-2,6-nonadienal と 3,6-nonadien1-ol の耐成分の生成比によるものと推測されたが，それ らの生成は全体の酵素の活性や基質特異性などによって 左右されるものと考党られる。LOX 様酵著は天然了二 と荃殖つユとの間に，活性や基質特異性などについて差 が認められなかったが, in vitro に叔けるポリエン酸の 
最終産物であるC $C_{9}$ カルボニルとアルコールの生成比に ついては，両者の間に明らかな善がみられた。このこと から天然扣よび羡殖アニの番気の違いは Fig. 4 に示す 醅素 3 と䣼 4 による影響が大きいと推测される。

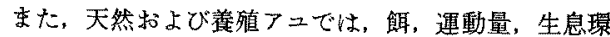
境などは明らかに異なる。これらの因子はアユの脂肪酸 や酵素系に影響を及任すにらがいない。アユ組維の脂肪 酸は䬣飼料の影響を受けることが知られている。 位別上季節に上る天然执よび盖殖アユの全脂肪酸組成の

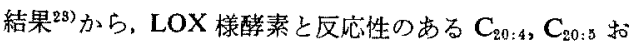

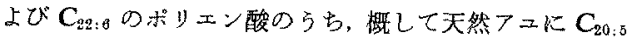
(EPA) が荃殖アユより多いことが珰められた。一方，配 合試料上異なり天然餌料である忖着藻類には $\mathrm{C}_{18: 3}$ が多

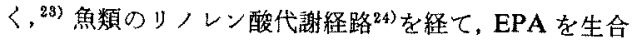
成することが考えられる。そのはか天然アユはなおばり をつくり，つねに激しい本流中に生息しているのに対し

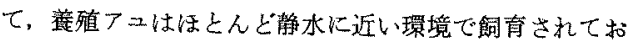
り，運動量により体内の酵素系の性質が違いを生ずるこ 上お考劣られる。ア二香気に対するこれらの因子による 影響については今啳の研究に期待される。

本研究を行らに当たり，LOXによる代謝産物モ，ヒ ドロキシ酸の湘定法について、ご助言をいたたいた広島 大学生物生虐学部の飯島憲章博士，扣上び天然了ニの入 手について多大にご協力していただいた栃木県水産試験 場の方々に感謝する。

\section{文暗}

1) T. Hirano, C.-H. Zhang, A. Morishita, T. Suzuki, and T. Shirai: Identification of volatile compounds in ayu fish and its feeds. Nippon Suisan Gakkaishi, 58, 547-557 (1992).

2) C..H. Zhang, T. Hirano, T. Suzuki, and T. Shirai: Enzymatically generated specific volatile compounds in ayu tissuess. Nippon Suisan Gakkaishi, 58, 559-565 (1992).

3) J. B. German and R. K. Creveling: Identification and characterization of a 15-lipoxygenase from fish gills. $J$. Agric, Food Chem., 38, 2144-2147 (1990).

4) J. B. German, G. G. Bruchner, and J. E. Kinsella: Lipoxygenase in trout gill tissue affecting on arachidonic, eicosapentaenoic, and docosahexaenoic acids. Biochim. Biophys. Acta, 875, 12-20 (1986).

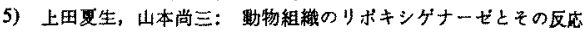
性，费化鮚，62, 50-54 (1988).

6) R. J. Hsieh, J. B. German, and J. E. Kinsella: Lipoxygenase in fish tissues: Some properties of the 12-lipoxygenase from trout gill. J. Agric. Food Chem., 36, 680685 (1988)

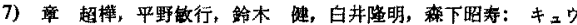

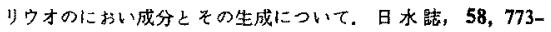
779 (1992).

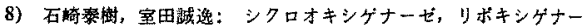

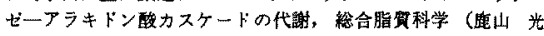

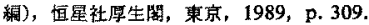

9) R. J. Hsieh and J. E. Kinsella: Lipoxygenase generation of specific flavor carbonyl compounds in tish tissues. $J$ Agric. Food Chem., 37, 279-286 (1989).

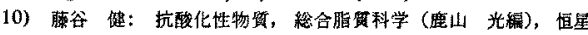
社厚生閣, 東京, 1989, pp. 616-628.

11) D. B. Josephson, R. C. Lindsay, and D. A. Stuiber: Enzymic hydroperoxide initiated effects in fresh fish. J. Food Sci., 52, 596-600 (1987).

12) D. A. Forss, E. A. Dunstone, E. H. Ramshaw, and W. Stark: Flavor of cucumbers, J. Food Sci., 27, 90-93 (1962).

13) T. R. Kemp, D. E. Knavel, L. P. Stoltz, and R. E. Lundin: 3,6-Nonadien-1-ol from Citrullus vularis and Cucumis melo. Phytochemistry, 13, 1167-1170 (1974).

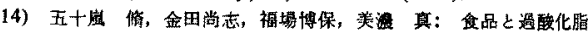

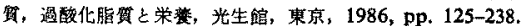

15）南出院久: 果实，野菜の脂害とりボキシダナーゼの生理作用， 日諶工誌，24，186-199(1977)

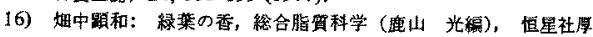
告闌。柬京, 1989, pp. 845-858.

17) A. Hatanaka, J. Sekiya, and T. Kajiwara: Enzyme system catalyzing formation of $c i s$-3-hexenal and $n$-hexanal from linolenic acid and linoleic acid in Japanese Silver (Farfugium japonicum Kitamura) leaves. Plant Cell Physiol., 18, 107 116 (1977).

18) A. J. Macleod and H. E. Pikk: Formation of (E)-hex2-enal and (Z)-hex-3-en-1-ol by fresh leaves of brassica. J. Agric. Food Chem., 27, 469-475 (1979).

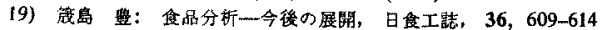
(1989).

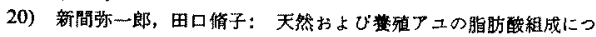
证, 日水誌, 30, 918-925 (1964)

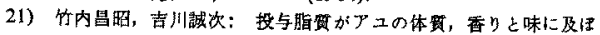

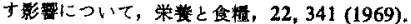

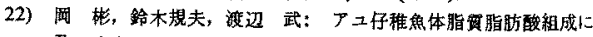
及隹すタマシシンコ脂勘酸の影， 日水誌，48, 1159-1162 (1982).

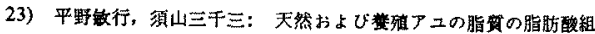

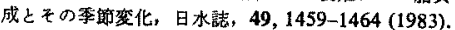

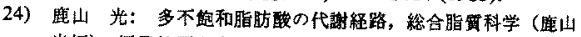

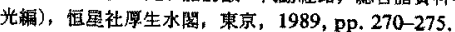

